\title{
Professor Ralph Clement Bryant
}

Professor Ralph Clement Bryant, a member of the faculty of the Yale School of Forestry for over thirty-two years, and a former president of the Society of American Foresters, died of pneumonia at the New Haven Hospital on February 1 last. He was professor of Lumbering at Yale, and was described by Dean Henry $S$. Graves of the Yale School of Forestry as "a pioneer educator and leader in his special field of lumbering in all its economic and technological aspects."

A native of Princeton, Illinois, and a grand-nephew of William Cullen Bryant, Professor Bryant was the first graduate of the College of Forestry at Cornell University in 1900. In 1907 the lumber manufacturers of the country joined in giving an endowment fund to the Yale School of Forestry for educational work in applied forestry and lumbering, and Professor Bry. ant was chosen to fill that chair. When he came to Yale he had already a background of experience in the Bureau of Forestry in the Philippine Islands, of which he was Assistant Chief.

$\mathrm{He}$ served as president of the Society of American Foresters for two terms, had been a member of its Executive Council, and chairman of various connnittees concerned with wood utilization problems. He was the author of two text books entitled "Logging" and "Lumbering."

"His constructive work during his long service at Yale is widely recog. nized both in educational circles and throughout the country," Dean Graves said. "His books and numerous other publications have had wide influence in forest schools and among practicing foresters and lumbermen."

"Professor Bryant was a man of cultivation, wide interests and personal charm. He had keen perception and sound judgment, which added to his influence in guiding the affairs of the School of Forestry and of other organizations with which he was affiliated. His personal qualities of considerateness and interest in others drew to him a host of friends. His loss will be deeply felt by the University, and especially by his immediate col. leagues who were attached to him by unusual bonds of admiration and affection." 